\title{
Estimation of the coal fired heat plant energy efficiency increase after heat recovery from flue gas cooling down below the dew point
}

\author{
Piotr Ostrowski ${ }^{1,1}$ Filip Szelejewski ${ }^{2}$ \\ ${ }^{1}$ Division of Boilers and Steam Generators, Institute of Power Engineering and Turbomachinery, \\ Konarskiego 20, 44-100, Gliwice, Poland \\ ${ }^{2}$ N-ERGIA Sp. Z o.o., Konarskiego 18C, 44-100, Gliwice, Poland
}

\begin{abstract}
The paper shows a method of the assessment of the energy efficiency of a modernised steam boiler house in which the thermal energy is recovered due to cooling of the flue gas below dew point. In addition to the energy recovery the modernisation also consists of a wet flue gas treatment that ensures a reduction in emissions of particulates and acidic gas. The publication presents the correct and simple indicator for the assessment of improvement of energy efficiency. Additionally some recommendations based on the example of settlement of savings made in hard coal heating plant, equipped with three steam boilers, fire-tube type, with a capacity of $3 \times 3.0 \mathrm{t} / \mathrm{h}$, operating with quasi-constant output during the year are shown.
\end{abstract}

\begin{tabular}{|c|c|c|}
\hline \multicolumn{3}{|l|}{ yymbols } \\
\hline$m_{S T}$ & $t / h$ & steam flow rate exiting the boiler \\
\hline$m_{S T S P}$ & $t / h$ & $\begin{array}{l}\text { plant's own consumption, } \\
\text { boiler house consumption (boiler house heating + deaerator): }\end{array}$ \\
\hline$m_{\text {STONb }}$ & $t / h$ & steam flow rate before modernization, \\
\hline$m_{\text {STONa }}$ & $t / h$ & steam flow rate after modernization, \\
\hline$h_{S T}$ & $\mathrm{~kJ} / \mathrm{kg}$ & $\begin{array}{c}\text { specific enthalpy of saturated steam (for 1,12MPa; } h_{S T}=2782 \\
\mathrm{~kJ} / \mathrm{kg}),\end{array}$ \\
\hline$h_{F W}$ & $\mathrm{~kJ} / \mathrm{kg}$ & spec. enthalpy of feed water (for $\left.t_{F W}=105^{\circ} \mathrm{C} ; h_{F W}=440,2 \mathrm{~kJ} / \mathrm{kg}\right)$, \\
\hline$h_{F W}^{\prime}$ & $\mathrm{kJ} / \mathrm{kg}$ & $\begin{array}{c}\text { spec.en. of water enter. deaerator }\left(\text { for } t_{F W}^{\prime}=60^{\circ} \mathrm{C} ; h_{F W}^{\prime}=251,1\right. \\
\mathrm{kJ} / \mathrm{kg}),\end{array}$ \\
\hline$t_{F W}$ & ${ }^{\circ} \mathrm{C}$ & boiler feed water temperature/from the deaerator $\left(t_{F W}=105^{\circ} \mathrm{C}\right)$, \\
\hline$m_{F}$ & $\mathrm{~kg} / \mathrm{h}$ & hard coal consumption, \\
\hline$m_{F b}$ & $\mathrm{~kg} / \mathrm{h}$ & hard coal consumption before modernization, \\
\hline$m_{F a}$ & $\mathrm{~kg} / \mathrm{h}$ & hard coal consumption after modernization, \\
\hline$H_{(N)}$ & $\mathrm{kJ} / \mathrm{m}^{3}{ }_{N}$ & hard coal lower heating value $\left(H_{(N)}=22840 \mathrm{~kJ} / \mathrm{kg}\right.$ in Feb.2017), \\
\hline$H_{(G)}$ & $\mathrm{kJ} / \mathrm{m}^{3}{ }_{N}$ & hard coal higher heating value $\left(H_{(G)}=24140 \mathrm{~kJ} / \mathrm{kg}\right.$ in Feb.2017), \\
\hline
\end{tabular}

${ }^{1}$ Corresponding author: piotr.ostrowski@polsl.pl 


\begin{tabular}{|c|c|c|}
\hline$h_{e v}$ & $\mathrm{~kJ} / \mathrm{m}^{3}{ }_{N}$ & $\begin{array}{l}\text { increase in the enthalpy of vaporization (condensation) from flue } \\
\text { gas cooling, after lowering the dew point temperature }\end{array}$ \\
\hline$h_{F}$ & $k J / k$ & $\begin{array}{l}t_{R h 1} \text { and } t_{R h 2,}, \quad h_{e v}=h_{e v G R h 1}-h_{e v G R h 2,} \\
\text { specific enthalpy of hard coal }\left(c_{F}=1,26 \mathrm{~kJ} /(\mathrm{kg} \mathrm{K}) \text {, }\right.\end{array}$ \\
\hline & & f combusti \\
\hline$\mu_{A}$ & $\begin{array}{c}\mathrm{kg}_{A} / \mathrm{kg} \\
{ }^{\circ} \mathrm{C}\end{array}$ & $\ln r$ \\
\hline & & $\begin{array}{c}\text { temperatures: flue gas, dew point at the inlet to the HRS } \\
\text { installation, }\end{array}$ \\
\hline$t_{R h 2}, t_{r G 2}$ & ${ }^{\circ} \mathrm{C}$ & $\begin{array}{c}\text { temperatures: flue gas, dew point at the outlet to the HRS } \\
\text { installation, }\end{array}$ \\
\hline$Q_{E}$ & & $\begin{array}{c}\text { useful heat (with quasi constant conditions in the boiler work } \\
\text { point and negligible small loss of blow down) }\end{array}$ \\
\hline
\end{tabular}

Losses proportional to the fuel mass flow rate:

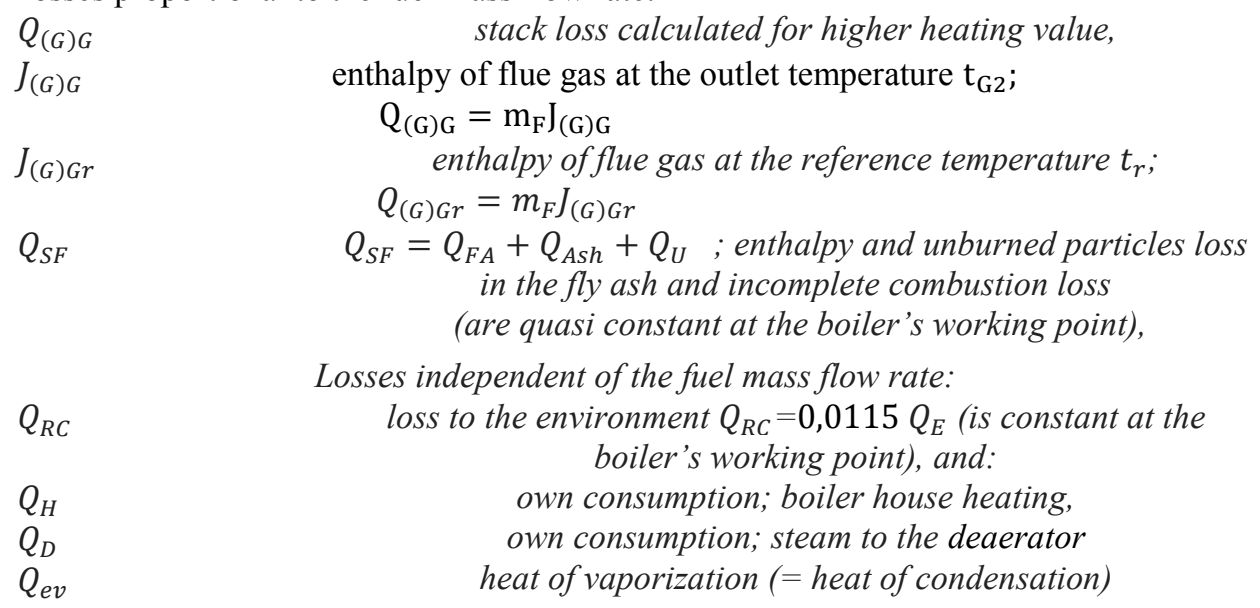

\section{Introduction}

The Energy Law [1] and the Energy Efficiency Act [2] force the Industrial Plants to take measures to improve energy efficiency. Activities should start from the energy audit in accordance with PN-EN 16247-3: 2014 [4] and [3], and end with the implementation of modernization proceeded by submission of an appropriate application for the guarantee of origin (so-called White certificates, which are the energy recipient's remuneration for effective use of final energy and energy services).

Among the undertakings aimed at improving energy efficiency in art.19, the following were indicated:

- point 3 - modernization or replacement c) local heating networks and local heat sources...;

- $\quad$ point 4 - energy recovery, including energy in industrial processes.

The purpose of the paper was to show the different approach in the calculation of the savings with comparison to [4] and [3] based on a real industrial example- boiler house equipped with three coal fired steam boilers. One can see that compared to author's 
calculation the understatement of the savings can be significant and lead to submission of incorrect application of the White certificates.

\section{Industrial and municipal boiler houses}

As a boiler house we understand: boiler itself with associated equipment such as initial preparation and supply of media and the separation of products.

In the vast majority of boilers built in previous years, the outlet temperature of the flue gas to the environment is traditionally maintained in the range of $130-160^{\circ} \mathrm{C}$ for water tube boilers and $230^{\circ} \mathrm{C}$ for fire-tube boilers, due to the risk of overcooling the flue gas below the acid dew point. This relatively high flue gas temperature implies high stack loss, which limits the energy efficiency of gas (and oil) boilers up to approx. 89\%, pulverized coal boilers up to approx. $87 \%$ and grate type boilers up to approx. $79 \%(72 \%)$ in relations to the higher calorific value of the fuel.

The described conditions encourage to search for other ways to increase the energy efficiency of the boiler house, by taking over the heat power recovered from lowering flue gas temperatures below the dew point from the devices in boiler house [8,9].

In recent years, the Division of Boilers and Steam Generators of Institute of Power Engineering and Turbomachinery of the Silesian University of Technology has carried out concepts and balance calculations of the heat recovery and heat management installation called EWHR (Ecological Waste Heat Recovery). The system is mainly aimed for industrial boilers fired with gaseous fuels, hard coal combusted on the grate or dust burners.

Below based on the recommendations [10] and [11] method of the boilers energy efficiency calculation for this type of boilers using direct and indirect method is presented, also for boilers with condensation of flue gas. After accepting the balance boundary and introducing additional markings, the energy efficiency of the boiler house before and after modernization was calculated-in relation to the higher heating value $H_{(G)}$. It should be noted that balancing of the condensing boilers with respect to lower heating value is from a formal point of view incorrect because it may yield results exceeding $100 \%$. However, it is sometimes used to show an improvement in energy efficiency in relation to the state before modernization, when the water contained in the exhaust did not undergo condensation.

\section{The energy efficiency of a boiler house equipped with stoker steam boilers}

\subsection{The energy efficiency of a stoker boiler}

Based on the recommendations contained in the standards [8] and [9] the method of calculating the energy efficiency of steam, stoker, fire-tube (stb) or water tube (wtb) boilers using direct and indirect method is presented below: 


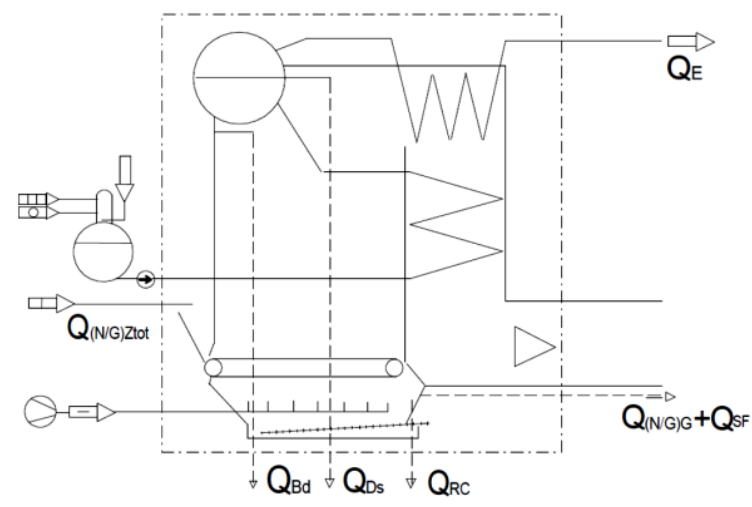

Media:

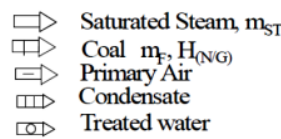

Balance boundaries:

Fig. 1. Stoker boiler scheme.

$\eta_{(G) B}$

boiler energy efficiency expressed as the ratio $Q_{E}$ of useful thermal power, transferred to the steam and/or water, to $Q_{(G) Z \text { tot }}$ energy stream supplied to the boiler in relation to the higher heating value $H_{(G)}$.

When there are no other energy streams $Q_{(G) Z}=0$ and whole fuel is combusted $I_{U}=0$ then $Q_{(G) Z t o t}=m_{F} H_{(G) t o t}$

$$
\text { and } H_{(G) t o t}=\left[\left(H_{(G)}+h_{F}\right)+J_{A}\right]=\left[H_{(G)}+c_{F}\left(t_{F}-t_{r}\right)+\mu_{A} c_{A}\left(t_{A}-t_{r}\right)\right]
$$

Boiler energy efficiency

$$
\eta_{(G) B}=\frac{Q_{E}}{Q_{(G) Z t o t}}
$$

Calculated directly

$$
\eta_{(\mathrm{G}) \mathrm{B}}=\frac{\mathrm{m}_{\mathrm{ST}}\left(\mathrm{h}_{\mathrm{ST}}-\mathrm{h}_{\mathrm{FW}}\right)}{\mathrm{m}_{\mathrm{F}} \mathrm{H}_{(\mathrm{G}) \text { tot }}}
$$

Calculated indirectly

$$
\eta_{(G) B}=\frac{m_{F} H_{(G) \text { tot }}-\left(Q_{(G) G}+Q_{R C}+Q_{S F}\right)}{m_{F} H_{(G) t o t}}
$$

In the equation (3) total loss has been marked as follow:

Total loss

$$
\begin{gathered}
\sum Q_{\text {tot }}=Q_{(G) G}+Q_{F A}+Q_{A s h}+Q_{u}+Q_{R C} \\
Q_{\text {tot }}=Q_{(G) G}+Q_{S F}+Q_{R C}
\end{gathered}
$$

after neglecting negligible small losses $\mathrm{Q}_{\mathrm{Bd}}=0, \mathrm{Q}_{\mathrm{Ds}}=$ 0

For example, for the ERm 3,0/13 barg steam boiler used in the example the determined energy efficiency is $\eta_{(G) B}=74 \%$ 
Energy efficiency $\eta_{(G) B}$ is used for boilers with steam condensation in flue gas and equation (2) has been used for its calculation.

Determining the energy efficiency of the hard coal fired boiler house as $\eta_{(G) B R}$ (Boiler House Energy Efficiency $\left.\eta_{(G) B R}\right)$, one can calculate:

\subsection{The energy efficiency of the hard coal fired boiler house before modernization $\eta_{(G) B R b}$ (based on higher heating value of the fuel $\mathrm{H}_{(G)}$ )}

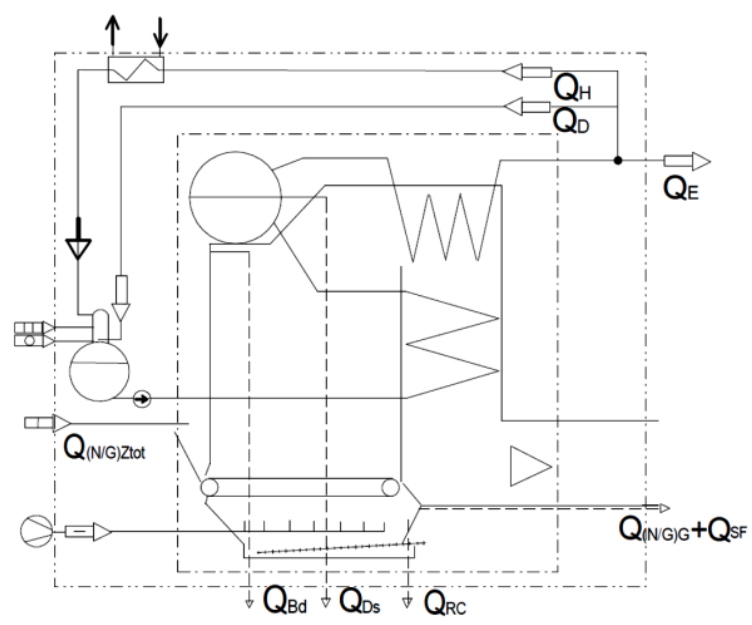

Fig. 2. Boiler house scheme.

\author{
Media: \\ $\Rightarrow$ Saturated Steam, $\mathrm{m}_{\mathrm{ST}}$ \\ ㅁ Coal $\mathrm{m}_{\mathrm{F}}, \mathrm{H}_{(\mathrm{N} / \mathrm{G})}$ \\ ㄱ) Primary Air \\ ए1) Condensate \\ (O) Treated water
}

Balance boundaries:

-.-.- Boiler

$\ldots$ Boiler house

Negligible losses:

QBd QD

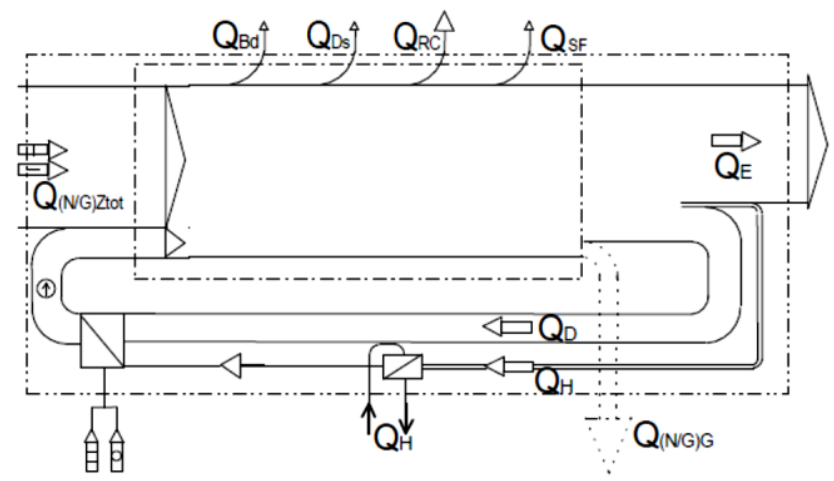

Losses:

$Q_{B d}=0 \quad$ Blowndown Losses

$Q_{D s}=0$

QRc

Imperfect Loss

$Q_{\text {NG/ }} \quad$ Stack Loss

\section{Own needs:}

$Q_{H} \quad$ Boiler House Heating

Q D Deaerator

Balance boundaries:

-. - - - Boiler

_...... Boiler House

Fig. 3. Energy flow before modernization.

Calculated directly:

$$
\begin{array}{r}
\eta_{(G) B R b}=\frac{m_{S T S P}\left(h_{S T}-h^{\prime}{ }_{F W}\right)}{m_{F} H_{(G) t o t}}= \\
=\frac{m_{S T S P}\left(h_{S T}-h_{F W}\right)+m_{S T S P}\left(h_{F W}-h^{\prime}{ }_{F W}\right)}{m_{F} H_{(G) t o t}}
\end{array}
$$


but

$$
\mathrm{m}_{\mathrm{STSP}}=\mathrm{m}_{\mathrm{ST}}-\mathrm{m}_{\mathrm{STONb}}
$$

then

$$
\begin{gathered}
=\frac{m_{S T}\left(h_{S T}-h_{F W}\right)-m_{S T O N b}\left(h_{S T}-h_{F W}\right)+m_{S T S P}\left(h_{F W}-h_{F W}\right)}{m_{F} H_{(G) t o t}} \\
=\eta_{(G) B}-\frac{Q_{D}+Q_{H}}{m_{F} H_{(G) t o t}}+\frac{Q_{D}+Q_{H}}{m_{F} H_{(G) t o t}}
\end{gathered}
$$

after

$$
\eta_{(G) B R b}=\eta_{(G) B}
$$

all $=>$

Calculated indirectly:

$$
\begin{gathered}
\eta_{(G) B R b}=\frac{m_{F} H_{(G) \text { tot }}-\left[Q_{(N) G}+Q_{R C}+Q_{S F}\right]-\left[Q_{H}+Q_{D}\right]+m_{S T S P}\left(h_{F W}-h^{\prime}{ }_{F W}\right)}{m_{F b} H_{(G) \text { tot }}} \\
=\eta_{(G) B}-\frac{Q_{D}+Q_{H}}{m_{F} H_{(G) t o t}}+\frac{Q_{D}+Q_{H}}{m_{F} H_{(G) \text { tot }}}
\end{gathered}
$$

after

all $=>$

$$
\eta_{(G) B R b}=\eta_{(G) B}
$$

so the energy efficiency of the boiler house before modernization $\eta_{(G) B R b}$ is equal the boiler energy efficiency $\eta_{(G) B}$.

\subsection{The energy efficiency of the hard coal fired boiler house after modernization $\eta_{(G) B R a}$ (based on higher heating value of the fuel $\mathrm{H}_{(\mathrm{G})}$ )}

Marking:

$\eta_{(G) B R a}$ the energy efficiency of the hard coal fired boiler house after modernization (based on higher heating value of the fuel $H_{(G)}$ ):

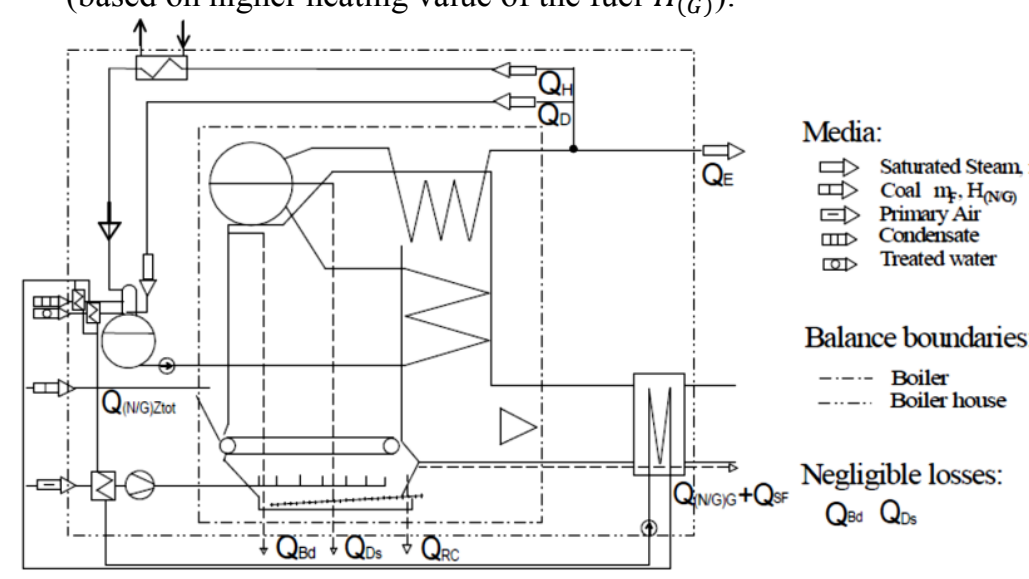

Fig. 4. Heat scheme of the boiler house. 


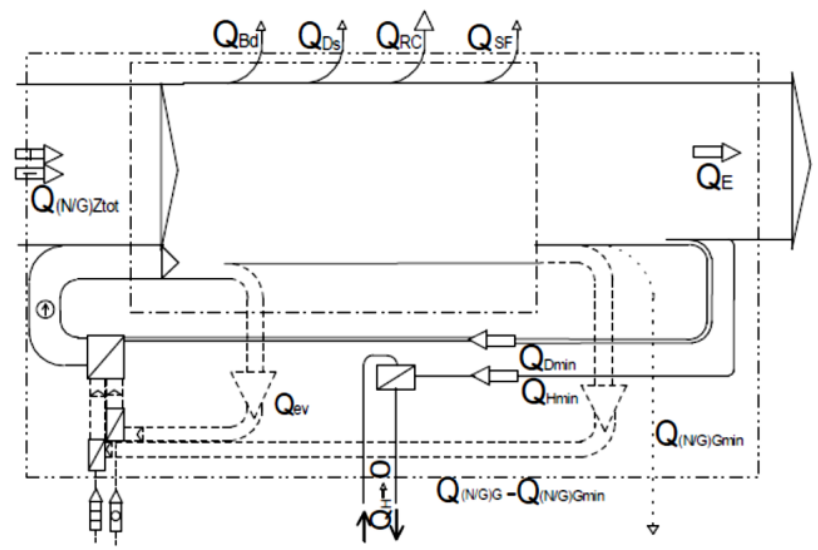

\section{Losses:}

$Q_{\mathrm{Ba}}=0 \quad$ Blowndown Losses

$Q_{\mathrm{AC}} \quad$ Heat Loss

$Q_{s f}=0 \quad$ Imperfect Loss

Q $\quad$ Stack Loss

\section{Own needs:}

$Q_{H} \rightarrow \min (0)$ Boiler House Heating $Q_{D} \rightarrow \min (0)$ Deaerator

Gains:

Qev Heat of condensation

\section{Balance boundaries:}

-.-.- - Boiler

_...... Boiler House

Fig. 5. Energy flow after the modernization.

$\mathrm{Q}_{\mathrm{ev}}$-heat of condensation (evaporation) from the flue gas cooling from the temperature $\mathrm{t}_{\mathrm{Rh} 1}$ to $\mathrm{t}_{\mathrm{Rh} 2}$

$$
Q_{e v}=m_{e v} h_{e v}=m_{e v}\left(h_{e v G R h 1}-h_{e v G R h 2}\right)
$$

Taking into account the mass balance of the steam (as above): $m==_{S T}=m_{S T S P}+m_{S T O N}$ the energy efficiency of the hard coal fired steam boiler house is determined:

\section{Explanation:}

1. $Q_{e v}$ has an effect on the higher heating value through $t_{A}\left(t_{A}\right.$ increases beyond balance boundary of the boiler)

$$
H_{(G) t o t}=\left[\left(H_{(G)+} h_{F}\right)+J_{A}\right]=\left[H_{(G)}+c_{F}\left(t_{F}-t_{r}\right)+\mu_{A} c_{A}\left(t_{A}-t_{r}\right)\right]
$$

2. Because in the energy efficiency formula $t_{F W}$ of the water is invariably $105^{\circ} \mathrm{C}$, the effect on the energy efficiency increase resulting from the sum of recovered heat equals the reduction of the stack loss by $\left[Q_{(G) G}-Q_{(G) G m i n}\right]$ increased by the introduced heat of condensation of the steam from flue gas $Q_{e v}$ which reduces the demand for steam streams to the deaerator $Q_{D \text { min }}$ and boiler house heating $Q_{H \text { min }}$. It is equal to the thermal power used outside the balance boundary to heat the air in the boiler house (see 1, increase $t_{A}$ and $t_{F}$ ) and heat the water to temperature $t_{F W 1}<105^{\circ} \mathrm{C}$ (e.g. $\left.t_{F W 1}=103^{\circ} \mathrm{C}\right)$. Water can be calculated from the formula $Q_{F W 0}=$ $m_{S T} 4.19\left(t_{F W 1}-t_{F W 0}\right)$ where $t_{F W 0}\left(\right.$ e.g. $\left.t_{F W 0}=60^{\circ} \mathrm{C}\right)$ is the water temperature (condensate + replenishment water) in the tank before the deaerator in the reference state i.e. without heat recovery.

FINALLY: total loss $Q_{\text {tot }}$ (see 2) after modernization will be smaller and will be equal $Q_{\text {tot }}-Q_{F W 0}$ which has been introduced to the formula (9) but with the higher heating value increase $H_{(G) \text { tot }}$ due to the increase of $t_{A}$ and $t_{F}$

\section{Calculated directly}

$$
\eta_{(G) B R a}=\frac{m_{S T S P}\left(h_{S T}-h^{\prime}{ }_{F W}\right)}{m_{F} H_{(G) t o t}}=\frac{m_{S T S P}\left(h_{S T}-h_{F W}\right)+m_{S T S P}\left(h_{F W}-h^{\prime}{ }_{F W}\right)}{m_{F} H_{(G)} \text { tot }}=
$$




$$
\begin{aligned}
& =\frac{\mathrm{m}_{\mathrm{ST}}\left(\mathrm{h}_{\mathrm{ST}}-\mathrm{h}_{\mathrm{FW}}\right)-\mathrm{m}_{\mathrm{STONa}}\left(\mathrm{h}_{\mathrm{ST}}-\mathrm{h}_{\mathrm{FW}}\right)+\mathrm{m}_{\mathrm{STSP}}\left(\mathrm{h}_{\mathrm{FW}}-\mathrm{h}_{\mathrm{FW}}\right)}{\mathrm{m}_{\mathrm{F}} \mathrm{H}_{(\mathrm{G}) \text { tot }}} \\
& =\frac{\mathrm{m}_{\mathrm{ST}}\left(\mathrm{h}_{\mathrm{ST}}-\mathrm{h}_{\mathrm{FW}}\right)-\left(\mathrm{Q}_{\mathrm{Dmin}}+\mathrm{Q}_{\mathrm{Hmin}}\right)+\mathrm{m}_{\mathrm{STSP}}\left(\mathrm{h}_{\mathrm{FW}}-\mathrm{h}_{\mathrm{FW}}\right)}{\mathrm{m}_{\mathrm{F}} \mathrm{H}_{(\mathrm{G}) \text { tot }}} \\
& \eta_{(G) B R a}=\eta_{(G) B}+\frac{-\left(Q_{D m i n}+Q_{H \text { min }}\right)+m_{S T S P}\left(h_{F W}-h_{F W}\right)}{m_{F} H_{(G) t o t}} \\
& \text { Calculated indirectly: } \\
& \eta_{(G) B R a}=\frac{m_{F} H_{(G) t o t}-\left[Q_{(G) G}+Q_{R C}+Q_{S F}\right]-\left[Q_{H}+Q_{D}\right]+m_{S T S P}\left(h_{F W}-h_{F W}\right)}{m_{F} H_{(G) t o t}} \\
& =\frac{\mathrm{m}_{\mathrm{F}} \mathrm{H}_{(\mathrm{G}) \text { tot }}-\left[\mathrm{Q}_{(\mathrm{G}) \mathrm{Gmin}}+\mathrm{Q}_{\mathrm{RC}}+\mathrm{Q}_{\mathrm{SF}}\right]}{\mathrm{m}_{\mathrm{F}} \mathrm{H}_{(\mathrm{G}) \text { tot }}}+\frac{-\left[\mathrm{Q}_{\mathrm{Dmin}}+\mathrm{Q}_{\mathrm{Hmin}}\right]+\mathrm{m}_{\mathrm{STSP}}\left(\mathrm{h}_{\mathrm{FW}}-\mathrm{h}_{\mathrm{FW}}\right)}{\mathrm{m}_{\mathrm{F}} \mathrm{H}_{(\mathrm{G}) \text { tot }}} \\
& \eta_{(G) B R a}=\eta_{(G) B}+\frac{-\left(Q_{D \text { min }}+Q_{H \min )+} m_{S T S P}\left(h_{F W}-h_{F W}\right)\right.}{m_{F} H_{(G) t o t}}
\end{aligned}
$$

\section{Example of economic evaluation of the steam generation process in a boiler house equipped with three steam stoker boilers fire-tube type $(3 \times 3.0 t / h)$}

\subsection{Description of heat recovery from flue gas and its management}

It follows from the above considerations that due to the lowering of the flue gas temperature exiting the boiler to the stack below the dew point, physical enthalpy of the flue gas can be recovered (cooling of the flue gas from approx. $225^{\circ} \mathrm{C}$ to approx. $45^{\circ} \mathrm{C}$ ) and latent $Q_{e v}$ (steam condensation from wet flue gas), which can be transferred to:

a) heating the returning condensate coming from the technological process and treated feeding water to the deaerator (up to $t_{F W}=105^{\circ} \mathrm{C}$ in the deaerator)

b) two-stage heating of the combustion air

- the first stage heats the external ambient air of the boiler house to approx. $25^{\circ} \mathrm{C}$ (during all year operation),

- the second stage heats the air above $50^{\circ} \mathrm{C}$ (temperature close to the final temperature of the cooled flue gas).

This organization of air heating ensures minimal stack loss $Q_{(G) G m i n}$.

It should be noted that in the process of cooling the flue gas with condensation, recovery of heating power and taking over this power to heat water before deaerator and combustion air in the boiler contributes into lowering the demand for fuel (coal). 


\subsection{Economic evaluation of the steam generation process}

Assuming the boiler energy efficiency $\eta_{(G) B R b}=74 \%$ related to the higher heating value of the fuel $H_{(G)}$ according to the parameters given by the manufacturer and measurement data from 2005 :

- in 2017 steam production (directed to the Plant and to the deaerator) amounted $38828000 \mathrm{~kg}$ during 8560 hours determining the average steam prod. $m_{S T}=4.536 \mathrm{t} / \mathrm{h}$ $\left(m_{S T}=1.26 \mathrm{~kg} / \mathrm{s}\right)$,

- saturated steam flow rate to the deaerator $m_{\text {STON }}^{\prime}=$ approx. $100 \mathrm{~kg} / \mathrm{h}\left(m_{\text {on }}=0.0278 \mathrm{~kg} / \mathrm{s}\right)$ hence the total production for technological process equal $4.536 \mathrm{t} / \mathrm{h}$

- water temperature in deaerator $t_{F W}=103^{\circ} \mathrm{C}$

- average ambient air temperature $t_{A}=-0.6{ }^{\circ} \mathrm{C}$ (Feb. 2017)

- specific enthalpy of the saturated steam produced by the boiler: $h_{S T}=2782 \mathrm{~kJ} / \mathrm{kg}$

- hard coal higher heating value $H_{(G)}=24136 \mathrm{~kJ} / \mathrm{kg}$ (readout from the reporting data of contractor),

Table 1. Steam consumption $\mathrm{t} / \mathrm{h}$ in 2016-2017

\begin{tabular}{|l|l|l|l|l|l|}
\hline & & 2016 & \multicolumn{2}{|l|}{$\begin{array}{l}\text { Steam division before } \\
\text { modernization in 2016 converted } \\
\text { into average steam yield in 2017 } \\
\text { (increased energy efficiency } \\
\text { compared to 2016) }\end{array}$} & $\begin{array}{l}\text { laverage } \\
\text { current } \\
\text { reading) }\end{array}$ \\
\hline 1. & $\begin{array}{l}\text { Technological } \\
\text { processes }\end{array}$ & 4.277 & 3.956 & \multirow{2}{*}{4.436} \\
\hline 2. & Plant heating & 0.480 & 0.48 & \multirow{2}{*}{0.436} \\
\hline 3. & $\begin{array}{l}\text { Deaerator } 60^{\circ} \mathrm{C} / \\
103^{\circ} \mathrm{C}\end{array}$ & 0.250 & 0.250 & 4.536 \\
\hline 4. & Boiler house heating & 0.323 & 0.323 & \\
\hline & Sum & 5.330 & 5.009 & \\
\hline
\end{tabular}

Above values were provided and accepted based on archive data on steam consumption in 2016 and water temperature in the intermediate tank $t_{W P}=60^{\circ} \mathrm{C}$. Data was taken from the period preceding the increase in demand and due to the fact it was recalculated proportionally to the current steam capacity of the boiler house for production and heating purposes in 2017 (as above $=4.536 \mathrm{t} / \mathrm{h}$ ). The results presented in the table above show the quantitative effects of modernization

The actual steam production for the boiler house in 2017 was $38828 \mathrm{t} / \mathrm{a}(=38828000$ $/ 8560 / 3600=1.26 \mathrm{~kg} / \mathrm{s})$. With known energy efficiency $\eta_{(G) B R b}=74 \%$ from equation (6)

$$
\eta_{(G) B R b}=\frac{m_{S T}\left(h_{S T}-h_{F W}\right)}{m_{F} H_{(G) t o t}} \text { calculated: }
$$

$m_{F}$ - annual demand for 3 boilers for hard coal before modernization.

$$
m_{F}=38828000 * \frac{2782-4.186 * 105}{0,74 * 24136}=5092394.51 \mathrm{~kg} / \mathrm{a}
$$


According to the report, hard coal consumption in 2017 was: 4488 200,00 kg/a hence saving coal consumption: $604195 \mathrm{~kg} / \mathrm{a}$ which corresponds to energy savings: $14582.8 \mathrm{GJ} / \mathrm{a}$ (4 $050.8 \mathrm{MWh}$ ) and for the average price in 2017 for hard coal $0.28 \mathrm{PLN} / \mathrm{kg}$ this means avoided spending: 169 174.5 PLN/a

\section{Evaluation of boiler energy efficiency improvement}

a) Boiler energy efficiency calculation based on higher heating value.

Boiler energy efficiency before modernization: 74\% (accepted or designated in the initial audit).

Average energy efficiency (based on the higher heating value) of each modernized boiler in reporting month of February was calculated according to equation (8). Calculated on the basis of the plant's production report (within a month or a year) steam production $38828000 \mathrm{~kg} / \mathrm{a}$ hard coal consumption $4488200 \mathrm{~kg} / \mathrm{a}$.

$$
\eta_{(G) B R b}=38828000 *[2782-4.186 * 105] / 4488200 / 24136=83.96 \%
$$

\subsection{Opinion on the need to amend the economic assessment of the steam generating process in the boiler house}

A typical algorithm recommended in audits calculates the current value of savings based on measurements of the recovered power taken and its summation in the reporting period, e.g. 1 month (monthly settlements).

For an exemplary steam boiler house $3 \times 3.0 \mathrm{t} / \mathrm{h}$ the savings (expenses avoided) are equal $\sim 80376 \mathrm{PLN} / \mathrm{a}$; this value is the sum of monthly settlements calculated according to the algorithm in the period 2017.

Actual savings in the boiler operation 169174.5 PLN/a outweigh the savings shown by $169174-80376=88798.5$ PLN/a which means that the actual profits of the Plant are higher by $110.0 \%$.

At this point, it should be noted that the Plant's submission for the modernization of the boiler house, the application for the allocation of the ,white certificates”, with incorrect calculation of savings will lead to understatement of the reported savings in the amount of 88798.5 PLN/a.

\section{Summary}

In an industrial steam boiler house, which is equipped with three stoker boilers, a modernization was carried out, which consisted in supplementing the installation with the recovery system cooling the flue gas below the dew point. The recovered thermal power was then supplied into the boiler installations, among others for heating up feed water, use for own needs (deaerating before the boiler and heating the boiler house) and heating the combustion air. In the installation, there is a wet exhaust purification system in parallel to ensure a reduction of VOC (Volatile Organic Compounds) emissions.

In the article, based on the recommendations included in the EN [8] and [9] standards, the method of calculating boiler energy efficiency using direct and indirect method is presented, also for boilers with flue gas condensing. After accepting the balance boundary and accepting additional markings, the energy efficiency of the boiler house before modernization and energy efficiency of the boiler room after modernization were calculated 
- in relation to the higher heating value $H_{(G)}$. In the publication the correct and simple indicator in the assessment of improvement of energy efficiency has been proposed. For a modernized boiler house in which the recovered waste heat (physical enthalpy and enthalpy of condensation recovered from the flue gas) is used in boiler devices (eg. deaerator, feed water heaters or air heaters for heating and combustion) the indicator has been shown as a difference in fuel consumption in the billing period in which the measured amount of energy produced (steam or heating water) and estimated fuel consumption was calculated in comparison with the same energy production for the boiler's energy efficiency preceding modernization (determined by the guarantee measurement). The selection of such indicator is justified by PN EN 50001:2011, Annex A. p.A.4.3 "Energy audit (...) is based on the appropriate measurement and observation of the current energy result..." and point A. p.A.4.5 "...the indicator of the energy result can be: energy consumption in time..." Such recommendation to correct determination of the energy efficiency index differs from the commonly used, incorrect practice of determining savings based on balancing the indications of meters of recovered and managed energy within the boiler house installations leading to incorrect accounting of savings both as a financial indicator of efficiency improvement of boiler house and as awarded bonus "White Certificates". The comparison of calculation results as above is a method of assessing the energy efficiency improvement of a stoker boiler house as a result of modernization. The recommendations elaborated are illustrated as example of accounting for savings arising in an industrial plant, equipped with three stoker steam boilers, flue and smoke tube type with a capacity of $3 \times 3.0 \mathrm{t} / \mathrm{h}$ operating with a quasiconstant load of about $80 \%$ a year.

\section{References}

[1] Prawo energetyczne DU RP z 06.02.2017 poz. 220 (jednolity tekst ustawy) Energy Law DU RP of 06.02.2017 item 220 (uniform text of the Act)

[2] Ustawa o efektywności energetycznej DU RP z 11.06.2016 poz. 832 Act on energy efficiency DU RP of 11.06.2016 item 832

[3] PN-EN 16247- 1:2012 Energy audits - Part 1: General requirements

[4] PN-EN 16247- 3:2014 Energy audits - Part 3: Processes

[5] Commission Implementing Decision (EU) 2017/1442 of 31 July 2017 establishing best available techniques (BAT) conclusions, under Directive 2010/75/EU of the European Parliament and of the Council, for large combustion plants (notified under document C(2017) 5225).

[6] Dyrektywa Parlamentu Europejskiego i Rady 2010/75/UE z dnia 24 listopada 2010 r. w sprawie emisji przemysłowych (zintegrowane zapobieganie zanieczyszczeniom i ich kontrola) (Dz. Urz. UE L 334 z 17.12.2010, str. 17, z późn. zm.) Directive 2010/75 / EU of the European Parliament and of the Council of 24 November 2010 on industrial emissions (integrated pollution prevention and control) (Of. Journal of the European Union L 334, 17/12/2010, page 17, with late changes).

[7] Rozporządzenie MŚ. w sprawie standardów emisyjnych dla niektórych rodzajów instalacji, źródeł spalania paliw oraz urządzeń spalania lub współspalania odpadów. DU RP z 4.11.2014 poz.1546 Regulation of the Minister of the Environment regarding emission standards for certain types of installations, fuel combustion sources and waste incineration or co-incineration devices. DU RP of 4 November 2014, item 1546,

[8] R. Suntivarakorn, W. Treedet: Improvement of boiler's efficiency using heat recovery and automatic combustion control system. Energy Procedia 2016;100:193-7. 
[9] M. Terhan, K. Comakli: Design and economic analysis of a flue gas condenser to recover latent heat from exhaust flue gas. Appl. Therm. Eng. 100 2016;1007-1015 (2017).

[10] PN-EN 12953-11:2006 Shell boilers -Part 11: Acceptance tests

[11]PN-EN 12952-15:2003 Water-tube boilers and auxiliary installations -Part 15: Acceptance tests 